\title{
A Co-relationship Study of Cognitive Style and Language Activity Design in English Class
}

\author{
Wenqun Yao \\ Foreign Language School, East China Jiaotong University, Nanchnang Jiangxi, 330013 \\ wenqunyao@qq.com
}

Keywords: Cognitive Style Investigation; Language Activity Design; English Class; Effectiveness

\begin{abstract}
It is argued that learners' cognitive styles have close relationship their learning effectiveness. The present article explores the matching between students' cognitive styles and language activity design in English class. The study first investigated the cognitive styles of a certain group of students with Soloman's Learning Style Questionair; then designed and practiced proper language activities based on the investigation results. The study shows that for English class, the language activities based on cognitive style can help students cultivate the ability to better absorb information and present ideas as well, that is the languge competence. The results of study shows us the great value of cognitve styles in education field.
\end{abstract}

\section{Introduction}

The concept of cognitive style has been studied for many years. It was defined as individual's characteristic and typically preferred approaches or modes of perceiving, organizing and processing information[1] It is widely believed that there is no so-called good or bad cognitive styles and cognitive styles are relatively stable during a period of time.

There are various classifications of cognitive styles by scholars with different standards. The most famous one is "Field-depedent' \& "Field-independent" created by American psychologist Witkin in 1940's[2]. In 1990's British educationist Riding built two sets of cognitive style: "VerbalImagery" and "Wholist-Analytic". Riding regarded them as two parallel lines, each with two ending points and the middle continuous demension[3]. For individuals, his or her cognitive style changes inbetween, which is shown in Figure 1:

\begin{tabular}{|l|}
\hline the manner of information presenting \\
Verbal $\longmapsto$ Imagery \\
the manner of information organizing \\
Wholist $\longmapsto$ Analytic
\end{tabular}

Figure 1.
From 1970, cognitive style study has been applied in many areas including education. The inquiry, searching for empirical evidence to illuminate the association between cognitive styles and learning processes, has attracted many people's attention. More and more studies show that better learning outcomes are generally expected when there is a match between a learner's cognitive style and an

educational setting[4].

\section{Investigation of Cognitive Styles}

For any application of cognitive styles, it is needed to do the investigation of related cognitive styles. Our study is to explore the matching problem between students' cognitive styles and language activity design in English class.

Participants. The partipants of cognitive style investigation are a group of $1^{\text {st }}$-year graduates of science. Table 2 shows the detail information.

Table 1.

\begin{tabular}{|l|l|c|c|c|}
\hline \multirow{2}{*}{ participants } & \multicolumn{1}{|c|}{ major } & \multicolumn{2}{|c|}{ number } & average \\
\cline { 3 - 5 } & & boys & girls & age \\
\hline $1^{\text {st }}$ year graduates & $\begin{array}{l}\text { InformationTechnology } \\
\text { Managment }\end{array}$ & 31 & 9 & 23 \\
\hline
\end{tabular}


Instruments. The research team made use of the Soloman Learning Style Self-test[5] by Professor Babarra Solomon and her colleages from North Carolina State University to do the investigation. Learning style is the cognitve style in learning. The reason to choose Solomon Learning Style Self-test Table is that its comprehensive questions and easy operability. In self-test, cognitive styles are devided into 4 sets with each 2 types, they are "Active-Reflective", "PerceptiveIntuitive","Visual-Verbal" and "Sequential-Synthetical". For each set, there are 11 easy questions with choice of "a" and "b", 44 questions in total.

Table 2. Soloman Learning Style Self-test table (part )

\begin{tabular}{|l|l|l|}
\hline 1. In order to understand something, I & $\begin{array}{l}\text { 2. I like to be__ when dealing with } \\
\text { will first }\end{array}$ & problems \\
(a) try to do it. & (a) realistic. & \\
(b) think over it. & (b) creative. & \\
\hline
\end{tabular}

Table 3. Soloman Learning Style Self-test scoring sheet (part)

\begin{tabular}{|l|l|l|l|l|l|l|l|l|l|l|l|l|}
\hline \multicolumn{2}{|c|}{ "active-reflective" } & \multicolumn{3}{|l|}{ perceptive-intuitive } & \multicolumn{3}{|c|}{ visual-verbal } & \multicolumn{4}{|l|}{ sequential-synthesizing } \\
\hline Q & a & b & Q & a & b & Q & a & b & Q & a & b \\
\hline 1 & & & 2 & & & 3 & & & 4 & & \\
\hline
\end{tabular}

Data Anlysis. Cognition is a process involving information inputting, percepting, processing and managing. After the cognitive style investigation of the $1^{\text {st }}$-year graduates, our team organized the data intoTable 4.

Table 4.

\begin{tabular}{|l|l|l|l|l|l|l|l|}
\hline \multicolumn{2}{|l|}{ Information input } & \multicolumn{2}{l|}{ Information percepting } & Informationprocessing & \multicolumn{2}{l|}{ Information managing } \\
\hline $\begin{array}{l}\mathrm{a} \\
\text { visual }\end{array}$ & $\begin{array}{l}\mathrm{b} \\
\text { verbal }\end{array}$ & $\begin{array}{l}\mathrm{a} \\
\text { perceptive }\end{array}$ & $\begin{array}{l}\mathrm{b} \\
\text { intuitive }\end{array}$ & $\begin{array}{l}\mathrm{a} \\
\text { active }\end{array}$ & $\begin{array}{l}\text { b } \\
\text { reflective }\end{array}$ & $\begin{array}{l}\text { a } \\
\text { sequential }\end{array}$ & $\begin{array}{l}\text { b } \\
\text { synthestic }\end{array}$ \\
\hline 37 人 & 3 人 & 30 人 & 10 人 & 17 人 & 23 人 & 19 人 & 21 人 \\
\hline $92.5 \%$ & $7.5 \%$ & $75 \%$ & $25 \%$ & $42.5 \%$ & $57.5 \%$ & $47.5 \%$ & $52.5 \%$ \\
\hline
\end{tabular}

From Table 4, we found the big difference lie in the first two sets: $92.5 \%$ of the graduates tend to favor "a"(visual information) in information input and $75 \%$ choose "b" /"perceptive" in information percepting. Meanwhile, as for "Information Processing" and "Information Managing", the choice turned out to be balanced, almost half "a" and half " $b$ ". Therefore, generally, for the participants of $1^{\text {st }}$-year graduates, the cognitive styles in studying can be regarded as "Visual', "Percepting". "Reflective" and "Synthestic".

In order to know how far the participants go along the demension of each cognitive style, our team devided the test scores into 3 levels: strong $(9 a / 9 b-11 a / 11 b)$, morderate $(5 a / 5 b-7 a / 7 b)$ and weak $(a / b-3 a / 3 b)$. According to the Solomon scoring standard, the final score of each set of cognitive style may be any one within the score list: 11a、9a、7a、5a、3a、a、11b、9b、7b、5b、3b、b; in which the letter "a" or "b" stands for the concret type, the number before the letter stands for the degree of tense. For instance, for the first set cognitive style "Visual-Verbal", if the score is " $5 b$ ", it implies that the learner tends to like verbal information in moderate degree. After analyzing, the participants' degree in each cognitive type is revealed in Figure 2. 


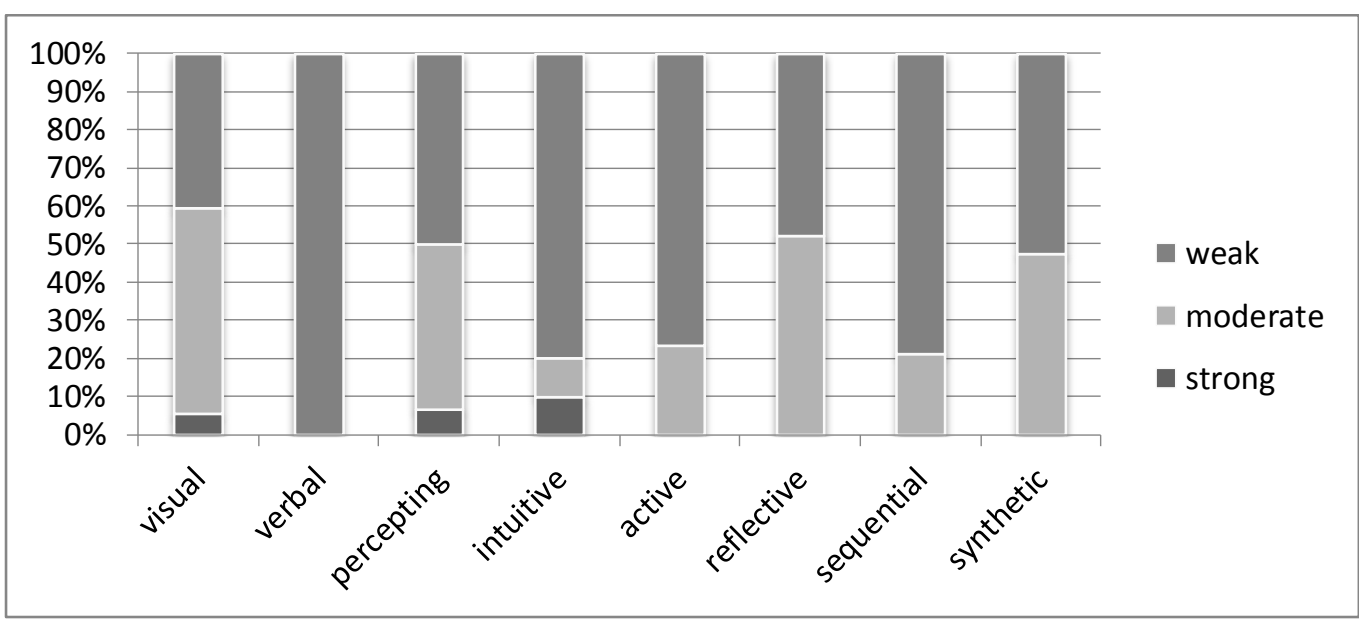

Figure 2. Participants' degree in each cognitive type

Set One Visual \& Verbal. Visual learners remember best what they see--pictures, diagrams, flow charts, time lines, films, and demonstrations. Verbal learners get more out of words--written and spoken explanations[6]. The bar graph shows that more than 50\% "Visual" type participants display moderate degree, about $40 \%$ weak degree, and less than $10 \%$ strong degree. For "Verbal" participants, all of them are in weak degree. So it may be concluded that for information inputting, the majority of the participants prefer visual informtion, such as colorful pictures or vedio movies, much more than printed or oral words.

Set Two Sensing \& Intuitive. Sensing learners tend to like learning facts, intuitive learners often prefer discovering possibilities and relationships[7]. The bar graph shows about 50\% "Perceptive" participants are in weak degree, 45\% moderate degree, 5\% strong degree. While about $80 \%$ "Intuitive" learners show weak degree. These data tell that the participants are better at the planned tasks or regular courses while uneasy at new conception learning or unexpected problems.

Set Three Active \& Reflective. Active learners tend to retain and understand information best by doing something active with it--discussing or applying it or explaining it to others. Reflective learners prefer to think about it quietly first[8]. In the bar graph, for "Active" type of participants, there are $80 \%$ weak learners and $20 \%$ mederate learners. On the other side, for "Reflective" type of participants, there are $40 \%$ weak learners and $60 \%$ mederate learners. Therefore, the fact is that more participants are used to thinking first before taking action and prefer to work individually instead of joining in a group in their studying as "Active"participants usually do in learning.

Set Four Sequential \& Global. Sequential learners tend to gain understanding in linear steps, with each step following logically from the previous one. Global learners tend to learn in large jumps, absorbing material almost randomly without seeing connections, and then suddenly "getting it." [9] The situation of Set Four is much the same like Set Three. There are about $80 \%$ weak "Sequential" participants and 20\% moderate ones. For "Synthetic" participants, half are weak in degree, half in moderate degree. It demostrates that the participants are inclined to finish tasks in a fast pace by integrateing the main points subjectively, rather than step by step in clear sequential order.

From the analysis above, conclusion can be drawn that this group of $1^{\text {st }}$-year graduates present their congnitive styles in learning as "Visual", "Peceptive" , "Reflective" and "Synthetic" with all in moderate degree.

\section{Application of Cognitive Style Investigation in English Class}

Language Activities Design in English Class. Class teaching is a comprehensive process involving many components, such as teaching contents, teaching devices, teaching plan, teaching bodies(teacers \& students) and so forth[10]. English class teaching, different from other classes, focuses on language input and output, that is, abilitity cultivating in listening, speaking, reading, 
and writing. It is necessary to design and carry out various proper kinds of language activities to train students to put English into real use.

Our team chose Unit 8 from Graduate English Book II as the teaching contents for our participants. In order to reach the goal of effective teaching, purposeful English language activities need to be designed referring to the cognitive style investigation of the participants. The following table is the design of language activities at different stages in class.

Table 5. Language activties design of Unit 8

\begin{tabular}{l|l|l}
\hline \multicolumn{3}{|c}{ Unit 8 Thinking Like a Mountain } \\
\hline Stage & \multicolumn{1}{|c}{ Detail language activity arrangements } & Notes \\
\hline Refore & $\begin{array}{l}\text { Activity One: video watching. (4 minutes) } \\
\text { A short clip of wolf from Animal World } \\
\text { Purpose: to get basic information about wolves. } \\
\text { Activity Two: oral description with wolves } \\
\text { pictures on PPT.(6 minutes) } \\
\text { Learners describe freely the image of wolves in } \\
\text { their mind. (no comments) }\end{array}$ & Visual input \\
\hline $\begin{array}{l}\text { While } \\
\text { Reading }\end{array}$ & $\begin{array}{l}\text { Activity Three: to fill in the chart of life circle in } \\
\text { mountains during the text learning.(5 mins) }\end{array}$ & Reflective input \\
\hline $\begin{array}{l}\text { Purpose:to highlight the theme of this unit } \\
\text { reading }\end{array}$ & $\begin{array}{l}\text { Activity Four: watch a film about wolves with the } \\
\text { same theme as the text. (10mins) } \\
\text { Purpose: to trigger more emotional thoughts about } \\
\text { wolf. }\end{array}$ & Video input \\
& $\begin{array}{l}\text { Activity Five: practise free writing with the help of } \\
\text { some key words. (20 mins) } \\
\text { Make a list of words about wolf and ask learners to } \\
\text { choose three to do a personal writing about wolves } \\
\text { and the environment in class. } \\
\text { Purpose:To strengthen the theme by comparing } \\
\text { students' previous and present ideas about wolves. }\end{array}$ & Synthetic output \\
\hline
\end{tabular}

Language Activities practice. After completing the teaching of Unit 8 with the designed language activities putting into practice one by one, we collected the feedback of the teacher and the learners and found three improvements in class. The first improvment is that the learners thought highly of the class with positive commends. Most expressed their fondness of such a kind of English class. The second is the increasing autonomy in the students' learning, making the class atmosphere more active than before. The third is students' deeper understanding of wolves and their value in the nature, which can be read clearly in students' free writing. All of these results can tell that the properly-designed language activities based on learners' cognitive styles is helpful to improve the effectiveness of class teaching.

Meanwhile, there are three findings. The investigation revealed that the participants are "Reflective" learners who are inclined to work alone, which is not the true in our class. In fact, the students like to join in groups to do tasks together. Maybe it is because our learners feel shy when staying alone and feel safe when in a group. So they like to work with others. Next, learners' cognitive styles not only affact the way of information presenting by teachers, but also determines the ways of information expressing by learners. In addition, although cognitive style is relatively stable, yet is not unchangeable[11]. Sometimes learners need to tail their old cognitive style to adapt to the specific situations, which is our teachers' duty to help them to make the adjustment. 


\section{Conclusions}

The paper explores the value of cognitive style investigation in guiding language activity design and application in English class. The collected data and anlyzed results both suggest that cognitive styles interact with the approach to organizeing and presenting learning contents, suggesting that a learner may learn more effectively in a learning environemnt where the contents are organized and presented in a way which matches his or her cognitive way [12].

\section{Acknowledgements}

This paper is a partial achievement of the Jiangxi Provincial Project of Education Revolution named

" Empirical Study of the Effectiveness of Multimodal Discourses in English Class Based on Cognitive Style Investigation”.

\section{References}

[1] Zhang,L.F.,Thinking Styles: Their Relationships with Modes of Thinking and Academic Performance, J. Educational Psychology. 22 (2002) 331-348.

[2] Witkin H A, Moore C A, Goodenough D R, Field-dependence and field-independence cognitive Style and their educational implications, J. Review of educational Research. 47(1977)1-64.

[3] Riding, R. J., Cognitive Styles Analysis, Learning \&Training Technology, Birmingham, 1991.

[4] Riding et al., translated by Weiguo Pang, Cognitive Styles and Learning Strategies. East China Normal University Press, Shanghai, 2003.

[5,6,7,8,9] Felder, R., \& Soloman, B., Learning styles and strategies. http//www. Ncsu. Edu/FelderPublic/ILSdir/Styles.

[10] Genshu Lu, Na Wei, Corelation Study between College Teachers' Conception of Teaching and College Students' Learning Styles, J. Teaching Research. 1(2010) 1-12.

[11] Xin Wu, Houcan Zhang, The Priliminary Application of ThinkingStyles Tests among College Students, J. Psyc hology Science. 3(1999) 293-297.

[12] Rui Zhang, The Individualized English Teaching Based on Learning Styles Differences, J. Continue Education Research. 11(2016) 134-136. 